\title{
ERBB2 Exon 20 Insertion Mutation
}

National Cancer Institute

\section{Source}

National Cancer Institute. ERBB2 Exon 20 Insertion Mutation. NCI Thesaurus. Code C150633.

A molecular genetic abnormality indicating the presence of an in-frame insertion mutation occurring within exon 20 of the ERBB2 gene. 